\title{
WAHBAH ZUHAILIY A SCHOLAR INTERPRETATION IN TWENTY CENTURY
}

\author{
Abd. Wahid \\ Ushuluddin Faculty of UIN Sultan Syarif Kasim Riau \\ Abd.Wahid@uin-suska.ac.id
}

\begin{abstract}
This essay reveal about a scholar who is steady to science for islamic advancement, trying to spread his message through a variety of writings throughout the world, he is Wahbah Zuhailiy, a Syrian scholar. Even if he is a scholar of Shariah experts, and having a lot of writing about fiqh, but he is also an expert interpretation, it is proved by there are three books of commentary written by him, one of the famous books is al-Tafsir Munir, through this book revealed the intention verses of the Qur'an more clearly. In interpreting the verse, he used methods maudhu'i, besides used Tahlili. Whilethe pattern, he tend to used Adabi Ijma ' $i$ and faqhi pattern. Although there are many praising to this interpretation, it still has many weakness, it is obviously what Wahbah Zuhailiy has put itself on the level of scholars interpretation of this century.
\end{abstract}

Keywords: Wahbah Zuhailiy, Islamic Scholar, and Tafsir

\section{Introduction}

The Qur'an is like a sea of vast, deep and not trimmed, filled with wonder and uniqueness, will never rotted with age and will not be destroyed because of learn, it's place to thought for people who want to think, as a sturdy rope to the looking for grip in order not to fall into the destruction. This phrase once expressed by a famous interpretation scholar, Jariri Ibn al-Tabari, in his preface Interpretation. As the book of Allah revealed al-Qur'an is the source of all sources of Islamic teachings. Holy book takes place on a central position where is not only in the development of Islamic science, but also as the inspiration and guiding for Muslim movements throughout this fifteen centuries of history of this movement. Therefore, it is necessary to explore the secrets of al-Qur'an, disclosed of ta'wil, so it has power for human life.
According to al-Suyuthi ${ }^{1}$ an effort to interpret al-Qur' an will bring the glory from three aspects. Firstly, if it reviews from the topic dealt with the word of God. Kalam Allah will give various knowledge like minerals this is multi-use; it is also like a judge deciding the case fairly, as well as the magic never stops. Secondly, when it viewed from the aspect of purpose, the object can bring endless ultimate happiness. And third, if it is judging from the aspect of importance, then all worldly affairs or hereafter perfection either sooner or later require shari'ah sciences and religious knowledge in accordance with the book of Allah, it is largest and important for Muslim progress and development. Therefore it is high attention of scholars to explore and understand the meanings contained in this Holy Book. There are many scholars who interprets al-Qur'an since

${ }^{1}$ Jalal al-Din Abd al-Rahman al-Suyuthi, al-Itqan fi Ulum al-Qur'an (Kairo: Dar al- Fikr, t.th), 175. 
Khalifah time to the present one is Wahbah Zuhaily. Even he is an expert in jurisprudence, but his attention in uncovering intent of al-Qur'an can be equated with other interpretations scholars.

Wahbah Zuhaily is one of fiqh scholars of 20th century noted from Syria. His name can be aligned with figures of Tafsir and fiqh which had been instrumental in the scientific world of Islam the 20th century, such as Tahir Assyrians who authored the interpretation of al-Tahrir wa alTanwir, Said Hawwa in Asas fi at-Tafsir, Sayyid Qutb in Fi Zhilal Al-Qur'an. While in fiqh, his name aligned with Muhammad Abu Zahra, Mahmud Syaltut, Ali Muhammad khafif, Abdul Ghani, Abdul Khaliq and Muhammad Salam Madkur. Most contemporary interpretations is from various scientific interpretations background, Wahbah Zuhailiy is a jurisprudents trying to decipher al-Qur'an verses by the sources, methods, style, and distinctive characteristics. ${ }^{2}$

\section{Biography of Wahbah Zuhailiy}

\section{A. His birth}

In $1932 \mathrm{AD}$, coincided with $1351 \mathrm{H}$ in the village of Dir Athiah Damascus Syrian was born baby who is then given the name Wahbah Zuhailiy. His father named Mustafa Zuhailiy got next to good deed and piety, he likes to learn Prophet Hadits, and memorize al-Qur'an, ${ }^{3}$ while the daily profession is as a farmer.

\section{B. Education and Profession}

As a farmer who lives in the village, Wahbah Zuhaily grow and develop with the rural atmosphere, that's where he got his early education that starts with basic education received in 1946 AD Later in secondary education, he

\footnotetext{
${ }^{2}$ Mohd Rumaizuddin Ghazali, "Wahbah Al-Zuhayli: Mufassir dan Ahli Fiqh Terkenal Abad ini", taken from http://www.abim.org.my/minda_madani/userinfo. php?uid=4.

${ }^{3}$ Abdul Ghafur Mahmud Mushthafa Ja'far, al-Tafsir wal Mufassirun fi Tsaubihi al-Jadid (al-Qahirat: Dar asSalam, 2007), 778-779.
}

entered the Department of Syari'ah in Damascus, education is traversed for 6 years, until in 1952 he got a diploma certificate. Persistence and determination studying is more fiery, he was not satisfied with a diploma in his hand. With a strong passion and confidently armed with a diploma certificate, he continued his studies at the Faculty of Syariah and Takhasus Arabic in Al-Azhar University and Syariah Faculty of 'Ain Syam University. In the same time, he obtained three certificates, they are: S1 of Syariah Faculty of A1Azhar University in 1956 AD, Takhasus Education certificate of Arabic Faculty of AlAzhar University in 1957 AD, and S1 Certicate of Syariah Faculty of 'Ain Syam University in 1957 AD. In the past five years, he was able to get three certificate from two different universities.

The spirit of studying again has not faded, his education continued to Post Graduate level at Cairo University which took two years, and obtained an M.A degree with a thesis titled "azZira'i fi as-Siyasah as-Syar'iy at wa al-Fiqh alIslami". It was not satisfied with his education, he went to a doctoral program which he completed in $1963 \mathrm{AD}$ and grabbed cum laude, with a dissertation entitled "Atsar al-Harb fial-FiqhalIsalmi" "under the guidance of Muhammad Salam Madkur. ${ }^{4}$

In professional field, he has held important positions in high education institutions. In 1963, he was appointed as a lecturer at the Syari'ah Faculty of Damascus University, and then he became Vice Dean at that University. In 19671970 he was appointed as Dean and Chairman of Department of Figh Islamic wa Madzahibuhu in the same faculty. There are many other professions in the field of Syariah, they are: as the head of Syari'ah supervisory studies of Islamic banking institutions and one of member panel of Syari'ah Islamic Bank. As a member of fiqh institutions in various countries, such as Mecca,

${ }^{4}$ Ibid., 779. 
Jeddah, Sudan, India, and America. He had also as head of syari' ah and Islamic law at University of United Arab Emirates for a year. He also served as a member of state institutions of Ahlul Bait institution of Islamic civilization research in Jordan. He had also appointed as supervisor of master's and doctoral candidate at Damascus University and Imam al-Auza'i University in Lebanon. He is the originator of Syariah Islamiyah Faculty at Damaskus University, and syari'ah wa al-Qanun at United Arab Emirates University. In 1988 AD, he was as a contributor of syariah magazine and Islamic Studies at Kuwait University, and in 1999 AD, he also involved in making method or planning syari'ah institution in Syria, and many more positions, professions, and his contribution to the human race, religion, and country. ${ }^{5}$

\section{The Teachers of Wahbah Zuhailiy}

A Muslim scholar does not grow and develop as it is, the role of a teacher plays an important role in develop scholars. It seems like Wahbah Zuhailiy, he has much teachers to seek knowledge, they are: He learned with Muhammad Hashim al-Khatib al-Syafi (w.1958) a preacher at Umawi Mosque. Studied theology was with Syaikh Muhammad ar-Rankusi. Faraidh science and Wakaf science were with Judat al-Mardini (w.1957), and Hassan al-Shati (w.1962). To Shaykh Hashim Khatib was in fiqh Shafi' $i$, while Ushul fiqh and mushtalah hadits were with Muhammad Lutfi al-Fayumi (w.1990). To Shaikh Ahmad as-Samaq was in Tajwid. Shaikh Hamdi Juwaijati was in the field of tilawat. Shaykh Abu al-Hasan al-Qasab was in nahwu and Sharf. In Tafsir, he learned with Syaikh Hasan Jankah and Sheikh Sadiq al-Maidani Jankah. While in the field of Arab science as Literature and Balaghat, he studied with Shaykh Salih Farfur, Syaikh Hasan Khatib, Ali Sa'duddin and Syaikh shubhi al-Khazran. Kamil al-Qasar to his study in the

${ }^{5}$ Zuhayli.com. field of Hadits and morality. He studied at khitab was with Mardini. In the field of morality and History, he studied with Rasyid Syathi, Hikmat Syathi and Nadhim Mahmud Nasimi. There are many other teachers in the fields of chemistry, physics, English and so forth of the modern sciences. ${ }^{6}$

During his stay in Egypt, he studied at alAzhar Grand Mahmud Syaltut (w.1963) Abdul Rahman Taj, Isa Manun in the field of fiqh muqaran (w.1376 H). Jad al-Rabb Ramadan (w.1994), Muhammad Hafiz Ghanim, Muhammad 'Abdu Dayyim in fiqh fiqh. Mustafa 'Abdul Khaliq and his son Abdul Ghani Usman marazuqi, Zhawahiri as-Shafi'i and Hasan Wahdan, he studied ushul fiqh. He studied fiqh syafi'I was with Mustafa Mujahid and fiqh Ibadah was with Muhammad 'Ali az-Za'bi. He studied fiqh Comparison and usul fiqh were with Abu Zahra, 'Ali Khafif, Muhammad Al-Bana, Muhammad Zafzaf, Muhammad Salam Madkur, Farj alSanhuri, and there are many teachers where he has absorbed their knowledge by Wahbah Zuhailiy. $^{7}$

\section{His Masterpiece}

Wahbah Zuhailiy is not only known as a scholar but also as an Islamic thought whose his thoughts are fairly easy to understand, the main points of his thoughts poured through writing in form of books. His books are exceed 133 books and when mixed with small tracts exceeds over 500 papers.

His books are as follows:

1. Atsar al-Harb fi al-Fiqh al-Islami - Dirasat Muqaranat, Dar al-Fikr, Damaskus, 1963.

2. Al-Wasit fi Usul al-Fiqh, Universitas Damaskus, 1966.

3. Al-Fiqh al-Islami fi Uslub al-Jadid, Maktabat al-Hadits, Damaskus.

\footnotetext{
${ }^{6}$ Ibid. see Bustanul Ulum.

${ }^{7}$ Ibid.
} 
4. Nazariat ad-Darurat asy-Syar'iyyat, Maktabat al-Farabi, Damaskus.

5. Nazariat ad-Daman, Dar al-Fikr, Damaskus, 1970.

6. Al-Usul al-Ammat li Wahdat ad-Din al-Haq, Maktabat al-Abassiyat, Damaskus, 1972.

7. Al-Alaqut al-Dawliat fi al-Islam, Muassasat al-Risalat, Beirut, 1981.

8. Al-Figh al-Islam Wa Adillatuhu (8 jilid), Dar al-Fikr, Damaskus.

9. Usul al-Fiqh al-Islami (dua Jilid), Dar al-Fikr al-Fikr, Damaskus.

10. Juhud Taqnin al-Fiqh al-Islami, Muassasat alRisalat, Beirut, 1987.

11. Fiqh al-Mawaris fi as-Shari'at al-Islamiat, Dar al-Fikr, Damaskus.

12. Al-Wasaya wa al-Waqf fi al-Fiqh al-Islami, Dar al-Fikr, Damaskus.

13. Al-Islam Din al-Jihad La al-Udwan, Persatuan Dakwah Islam Antarabangsa, Tripoli, Libya, 1990.

14. Al-Tafsir al-Munir fi al-Aqidat wa al-Syari' $\underline{a t}$ wa al-Manhaj, (16 jilid), Dar al-Fikr, Damaskus, 1991.

15. Al-Qisah al-Qur'aniyyat Hidayat wa Bayan, Dar Khair, Damaskus.

16. Al-Qur'an al-Karim al-bunyatuh atTasyri'iyyat aw Khasa'isuh al-Hadariat, Dar al-Fikr, Damaskus, 1993.

17. Ar-Rukhs $\underline{a t}$ as-Syari'at - Ahkamuha wa Dawabituha, Dar al-Khair, Damaskus, 1994.

In the field of interpretation, he has three books namely Tafsir Wajiz, interpretation and Tafsir Washith and Tafsir al Munir. However, The most famous is Tafsir al-Munir.

\section{The books of Tafsir Wahbah Zuhailiy}

As evidence of Wahbah Zuhailiy knowledge, he is not only experts in the field of fiqh but also in interpretation. This is evident with the present of three books of compiled Tafsir by Wahbah Zuhailiy. These three books are tafsir alWajiz, tafsir Wasshith and tafsir al-Munir.

\section{A. Tafsir Al-Wajiz}

In Tafsir Al-Wajiz, he modifies this interpretation in the form of notes or hasyiyat Mushaf. This interpretation only describes a little bit the meaning of every verse, and it explain some of words or sentences in al-Qur'an that according to him is very difficult to understand by public. On the sidelines of meaning of verses, he also present information about asbab an-nuzul. The purpose of him authored that interpretation is to help those who still lay in understanding the meaning of alQur'an verses. In Tafsir Wajiz, readers should be able to understand verses through asbab annuzul and also target of verse to be completely understood and then applied in life.

\section{B. Tafsir Al-Washith}

This interpretation book is a collection of his presentation through broadcast media for the Syrian population in general and then spread to many cities. In general, his schedule presented this interpretation at dawn every day for six hours, except on Friday, he did not appear because that day is holiday. This activity run for seven years, starting from 1992 until 1998, last, it is collected into interpretation al-Qur'an perfect into thirty juz. Tafsir which consists of three volumes printed in $1421 \mathrm{H}$ published by Dar al-Fikr Damascus. The characteristic of Tafsir Wajiz are: First, it has a sentence structure that is accurate or thorough, outlining each topic or theme evenly on every chapter, clear and easily understood by the reader. Secondly, the explanation of verse is only based on asbab an-nuzul of authentic history. hird, in arrange the interpretation, he really clings to Usul at-Tafsir that has been approved by scholars, and refer to famous interpretation books, and far from isra 'iliyat. Fourth, in exposing interpretation, Wahbah Zuhailiy explained based on gathered theme in several verses of surah complitely, then stepped to the next verses explain other themes. ${ }^{8}$ As he

${ }^{8}$ Multaqay al-Bayan Li Tafsir al-Qur'an, http://www.bayanalquran.net/forums/showthread.php?t=1280. 
interpret Surah al-Baqarah from the first verse into fifth verse which includes a theme about the nature of those who believe, and then he went on the set of verses contain unbelievers theme on sixth verses and seventh, and so on. ${ }^{9}$

\section{Tafsir al-Munir}

This interpretation book is the biggest book compiled by Wahbah Zuhailiy. This Book written in a span of 16 years after finishing writing two other books, namely Usul Fiqh alIslamy (in 2 volumes) and al-Fiqh al-Islamy wa Adillatuhu (in 8 volume). Tafsir al-Munir was first published by Dar al-Fikri Beirut-Lebanon and Dar al-Fikri Damascus, Syria in 16 volumes in $1991 \mathrm{M} / 1411 \mathrm{H}^{10}$

This interpretation has distinctive features compared to the Tafsir al-Washith and tafsir alWajiz. Tafsir al-Munir is broader and more detailed interpretation than his others interpretations, describes in detail the content of each Surah, containing the virtues Surah based on the authentic narrations and away from a weak history. It is continuous mutual between Surah and verse on partly surah and other verses. It presents a detailed and critical about the stories and tell sirah prophets. It is presenting syari'at law widely containing problem 'ubudiyah, 'aqidah, morality, 'Ibrah, and mauizhah hasanah, also contains on order of human life, interacting systems, and main points of Muslims life in general. In addition, this interpretation contains a detailed description of the simplex analyze sides Balaghat and $i$ 'rab. Such efforts, he did critically and carefully so his work completely clean of unwanted blemish, and priority to the miracles of the al-Qur'an in the face of civilization in this modern era.

Besides the differences between three interpretations, there are also similarities among

\footnotetext{
${ }^{9}$ Wahbah az-Zuhayli, Tafsir al-Wasith, surat al-Baqarah, hal 1/13, Kitab elektronik al-Islami.

${ }^{10}$ Multaqay al-Bayan Li Tafsir al-Qur'an. see Bustanul Ulum.
}

them, namely: Three interpretations are similar in terms of direction or purpose clause, described accurately and comprehensively, using uslub (arrangement) is simple and easy to understand, and to know asbab an-Nuzul of authentic history. Three of interpretation also have same steps in interpreting the verse, which is doing the interpretation and take proposition as an amplifier of the other verses and hadits from the authentic history according to the themes discussed.

\section{The Purpose of Tafsir al-Munir}

The purpose of this interpretation is suggested to Muslims to hold fast to al-Qur'an scientifically, because al-Qur'an is a matter of life which is very beneficial to mankind in general and Muslims in particular. Therefore, in his interpretation, he describes at length about the problems of fiqh, and laws which he analyze from al-Qur'an to explain the opinion of famous fuqaha (fiqh experts) even not in detail. He also explained the problems of Aqidah and Akhlaq, manhaj (procedure) in performing rituals, rules of syari'ah in general, adventages or the secrets of the verse, either express or implied, either in relation to the life of the community or public, or associated with individual or personal life, whether related to the life of the world, or the afterlife. ${ }^{11}$

In this case, Ali Iyazi in al-Mufassirun Hayatuhum wa Manhajuhum adding that the purpose of writing Tafsir al-Munir is to combine originality classic interpretation and the beauty of contemporary interpretation. Because according Wahbah Zuhailiy, there are many people who cornering that classic interpretation was not able to provide solutions to contemporary problems, whereas contemporary mufassir (interpretation expert) did irregularities interpretation of al-Qur'an under the pretext of renewal. Such as the interpretation of al-Qur'an made by some interpretation scholar that his

\footnotetext{
${ }^{11}$ Wahbah az-Zuhayli, Tafsir al-Munir, juz 1, p. 6 (1/1), Kitab elektronik al-Islami
} 
background knowledge is science. Therefore, according to him, classic interpretation should be packed with contemporary stylish and consistent method with modern science without any deviation interpretation. ${ }^{12}$ And most importantly that the target of tafsir al-Munir is to encourage and assist Muslims in tadabbur (analyze) alQur'an according to al-Qur'an guidelines, there is a tendency without any thought or sects, and even his interpretations product away from bigotry against the flow, sect, or any particular sect. ${ }^{13}$

\section{Methods (Manhaj)}

In his prologue, Wahbah Zuhaily explains in detail about the science that is closely associated with al-Qur' an that is needed in efforts to interpret al-Qur'an. Ahmad 'Atha 'Umar explained briefly presentation methodology of al-Qur'an interpretation. it was pursued by Wahbah Zuhailiy:

1. Grouping verses based on a theme, accompanied by a clear presentation.

2. Presents a description of each surah generally.

3. Provides an explanation of the language.

4. Clarify information verse with asbab an-nuzul is accountable history and discarding the weak narrations, and presenting the stories of prophets and great Islamic events, such as Perang Badr, Uhud, and others.

5. Interpret and explain in detail.

6. Analyze fiqh laws of verses interpreted.

7. Presenting verse explanation from i'rab and Balaghat to help those who need in these explanations.

8. Dribbling interpretation with Maudhu'i tafsir Model.

9. Terminate its interpretation by displaying some of references and sources that referenced his choice. ${ }^{14}$

\footnotetext{
${ }^{12}$ Bustanul Ulum.

${ }^{13}$ Multaqay al-Bayan Li Tafsir al-Qur'an.

${ }^{14}$ Ibid., Zuhayli, 12. see http://www.bayan-alquran.net/ forums/showthread.php?t=1280. Compare with Tafsir alMunir, juz 1, p. 10 (5/1), Kitab elektronik al-Islami, http:/ /b.m93b.com.
}

By observing several methods contained in books 'Ulum al-Qur'an. Methodically before discussing verses on every first Surah, Wahbah Zuhailiy always explain the significance and content of Surah first, it also describes a number of themes associated with an outline. Each of the themes raised and discussed include language aspect, to explain several of terms contained in a verse, by explaining balaghah aspects and grammar of the language. Thus, the method of interpretation used tahlili and maudlu' $i$ method. It can be noted in his interpretation in interprets alQur'an starting from the first surah to the last surah of al-Qur'an. It always give a theme on each study according to verse meaning, such as, in interpreting Surah al-Baqarah of first to fifth verses. He gave the theme of the characteristic of believers and reward for those pieties. So it went on until the last surah namely surah al-Nas. It always gives discussion theme in each group of verses interconnected.

\section{Pattern (Laun)}

There are seven pattern of interpretation as the opinions expressed by Abd al-Hayy alFarmawi in his book muqaddimat fi al-tafsir almaudhu'i. They are: al-tafsir bi al-ma'tsur, altafsir bi al-ra'yi, al-tafsir al-shufi, al-tafsir fiqh, al-tafsir falsafi, tafsir al-'ilm, and tafsir adabi 'ijtima'i. Thefore, the patterns of tafsir al-Munir by looking at the criteria, the writer can conclude that The interpretation is patterned 'addabi (literature), 'ijtima'i (social society), and fiqhi (fiqh), because Wahbah Zuhailiy has basic scientific in fiqh. However, in his interpretation he presents with style and meticulous editor, interpretation is also adapted to the evolving situation and it needs in society. He little use tafsir bi al-'ilmi, as it was already mentioned in the purpose of his writing that he will counter several contemporary interpretations deflection. ${ }^{15}$

\footnotetext{
${ }^{15}$ Multaqay al-Bayan Li Tafsir al-Qur'an.
} 


\section{Characteristics}

Muhammad Kalu in a forum to explain something that is typical in the book of alMunir interpretation is modified interpretation by different motives from previous interpretations, which serves a menu of interpretation products in one theme collected in several verses. For example, about partly crimes committed by Jews following punishment in receipt, then the theme is assembled in a few verses at the beginning of surah al-Baqarah. In addition, Tafsir al-Munir presents systematic interpretation and continuously, as follows: he presents al-i'rab, then move to alBalaghat, al-mufradat al-lughawiyat, asbab annuzul, at-tafsir wa al-bayan, and fiqh al-hayat aw al-Ahkam that all of it contained in each theme or verses are grouped. ${ }^{16}$ Then it include materials contained in ushul al-fiqh, to accommodate the debate that occurs between Islamic schools on interpretation of Ahkam verses, and take footnotes in citing others work. ${ }^{17}$

\section{Sources (mashadir) of Tafsir Munir}

Discussion of interpretation book uses a combination between tafsir bi al-ma tsur and tafsir bi ar-ra' 'yi, and use language style and expression is clear, namely contemporary style that is easy to understand for the current generation. Therefore, he divides verses by topic to keep the discussion and explanation in it. A lot of references used by Wahbah az-Zuhailiy in tafsir al-Munir include:

\section{a. Interpretation field}

1. Ahkam al-Qur'an work of Ibn al-'Arabi.

2. Ahkam al-Qur'an by al-Jashshas.

3. Al-Kasyaf work of Imam Zamakhsyari.

4. Al-Manar by Muhammad Abduh and Rasyid Ridha.

5. Al-Jami'fi Ahkam al-Qur'an by al-Qurtubi.

6. Tafsir Ath-thabary work of Muhammad bin Jarir Abu Ja'far ath-Tabari.

\section{${ }^{16}$ Ibid.}

${ }^{17}$ Bustanul Ulum.
7. At-Tafsir al-Kabir by Imam Fakhruddin Razi.

8. Majma'al-Fatawa work of Ibn Taimiyah.

9. Fath al-Qadir is Imam Ash-Syaukani work.

10. Mahasin at-Ta'wil work of al-Qasim.

11. Mashahif is Sajistani work.

12. Raudlat is an-Nadir works.

13. Ta'wil Musykil al-Qur'an by Ibn Qutaibah.

14. Tafsir al-Alusi works Syihab ad-Din Mahmud bin Abdillah.

15. Tafsir Al-Bahr al-Muhith work of Imam Abu Hayyan Muhammad bin Yusuf.

16. Tafsir al-Maraghi work of Mushtafa alMaraghi.

17. Tafsir Ayat al-Ahkam work of Syaikh Muhammad 'Ali as-Sayis.

18. Tafsir Ibn Kastir Ismail bin Umar bin Kathir.

19. Talkhis al-Fawaid work of Ibn al-Qash.

20. Tafsir al-Khazin work of Abu Hasan Ali bin Muhammad.

21. Tafsir Baidhawi work of al-Baidhawi.

\section{b. Field of Ulum al-Qur'an}

1. Asbab an-Nuzul work of al-Wahidi anNaisaburi.

2. Al-Itqan by Imam Suyuti.

3. Dalail al-I'jazz fi 'ilm al-Ma 'ani works of Imam Abd al-Qadir al-Jurjani.

4. Mabahistfi 'Ulum al-qur' an by Saleh Shubhi work.

5. Lubab an-Nuqul fi Asbab an-Nuzul by Imam Suyuti.

6. Asbab an-Nuzul work of al-Wahidi.

\section{c. Field of Hadits}

1) Al-Mustadrak by Imam Hakim.

2) Ad-dalail an-Nubuwwah work of Imam Baihaqi.

3) Al-kabir by ath-Thabrani.

4) Shahih al-Bukhari work of Muahammad bin Isma'il bin Ibrahim al-Bukhari.

5) Sunan Tirmidzi by Muhammad bin 'Isa Abu 'Isa at-Tirmidzi.

6) Musnad Ahmad bin Hanbal.

7) Nail al-Authar. 
8) Subul as-Salam.

c. Field of Ushul Fiqh and Fiqh

1) Bidayat al-Mujtahid karya Ibn Rusyd alHafidz.

2) Al-Figh al-Islami wa Adilatuh karya Wahbah az-Zuhailiy.

3) Usul al-Fiqh al-Islami karya Wahbah azZuhailiy.

4) Ar-Risalah karya Imam Syafi'i.

\section{d. Field of Theology}

1) Al-Kafi work of Muhammad bin Ya'qub.

2) Asy-Syafi Syarh Ushul al-Kafi by 'Abdullah Mudhhaffar.

3) Ihya 'Ulum ad-Din by Imam al-Ghazali.

\section{e. Field of Tarikh}

1) Sirah Ibn Hisyam Abu Muhammad bin Malik bin Hisyam.

2) Muqaddimah work of Ibn Khaldun.

3) Qashash al-Anbiya by Abd al-Wahhab anNajjar.

\section{f. Field of Luhgat}

1) Mufradat ar-Raghib by al-Ashfihani.

2) Al-Furuq work of al-Qirafi.

3) Lisan $a l-$ 'Arab by Ibn al-Mandhur.

\section{g. Field of Public}

1) Ar-Risalah Magazine.

2) Al-Muqtatif Magazine. ${ }^{18}$

\section{Advantages and Disadvantages}

Lots of scholars who praised the greatness of this interpretation because it has many advantages, one of them easily understood by the public except Arabic, because the language used quite simple, if it compared with other Turath books, while systematic of writing is not longwinded. This make easier to search for what is need, this interpretation makes a sub discussion with the theme that there is a correlation with the verses are interpreted and connects the verses with

\footnotetext{
${ }^{18}$ Bustanul Ulum.
}

the same verse. At the end of the discussion Wahbah Zuhailiy make conclusions verses interpreted, of course, in this case, it makes easy for reader and draw conclusions to be applied in everyday life.

Even though, there are many regard, it is not meant this interpretation having weaknesses or deficiencies. If it is seen accurately, this Tafsir has many compile many classical book and contemporary as if there is no gap shortcomings, but this is the weakness of tafsir. With the merging of classical and temporary book, it will seem as Wahbah Zuhailiy not put forward a new interpretation based on today's life. Beside, it is citing and held discussions with systematic more slick than existing books.

\section{Conclusion}

From the explanation above, it can be concluded that Wahbah Zuhailiy is one of Islamic scholar of deep knowledge and thinking, he is a preacher who preached through orally and written, either in the form of books or papers. He is an expert in the field of fiqh, and interpretation scholar in 20th century. He has compiled three books of tafsir namely alWajis, al-Washith and al-Munir. From the third books, Tafsir al-Munir is complete and more wellknown and widely used in various universities in the Islamic world. This Tafsir has been combine and summarize from various classical and contemporary interpretation, and use language that is easier understood by non-Arab, so it is difficult to find weaknesses. His skill in interpreting al-Qur'an makes him more popular in the Islamic world in twentieth century.

\section{Bibliography}

Ja'far, Abdul Ghafur Mahmud Mushthafa. alTafsir wal Mufassirun fi Tsaubihi al-Jadid. al-Qahirat: Dar as-Salam, 2007. 
Mohd. Rumaizuddin Ghazali. Wahbah AlZuhayli: Mufassir dan Ahli Fiqh Terkenal Abad ini. diakses dari http://www.abim. org. $\mathrm{my} / \mathrm{minda}$ madani/userinfo.php? uid=4.

Multaqay al-Bayan Li Tafsir al-Qur'an. diakses dari http://www.bayan-alquran.net/ forums/showthread.php?t=1280.

al-Qaradlawi, Yusuf. Bagaimana Beribteraksi dengan al-Qur'an. Diterjemahkan oleh Kathur Suhardi. Jakarta: Pustaka alKautsar, 2000.

al-Suyuthi, Jalal al-Din Abd al-Rahman. al-Itqan fi Ulum al-Qur'an. Kairo: Dar al- Fikr, t.th. az-Zuhayliy, Wahbah. Tafsir al-Wasith. Surat alBaqarah. Kitab elektronik al-Islami.

az-Zuhayliy, Wahbah. Tafsir al-Munir. Juz 1. 